Church, A., \& Rotolo, C. (2016). Lifting the veil: What happens when you are transparent with people about their future potential? People + Strategy, 39(4), 36-40.

Hambrick, D., \& Marquardt, M. (2018, February 6). Cognitive ability and vulnerability to fake news. Scientific American. Retrieved from https://www.scientificamerican.com/article/ cognitive-ability-and-vulnerability-to-fake-news/.

Hogan, R. (2016). The accident-prone personality. People + Strategy, 39(1), 20-23.

Johnson, B. (2014). Polarity management: Identifying and managing unsolvable problems. Amherst, MA: HRD Press, Inc.

Kahneman, D. (2011). Thinking, fast and slow. New York, NY: Farrar, Strauss, and Giroux.

Klimoski, R. (2016). Critical success factors for cybersecurity leaders: Not just technical competence. People + Strategy, 39(1), 14-18.

Lin, L, Nolan, K., \& Dalal, D. (2018, April). Communicating with organizational leaders: Selling our intervention. Community of Interest presented at the 33rd Annual Conference of the Society for Industrial and Organizational Psychology, Chicago, IL.

Nieminen, L., Bianco, C., \& Denison, D. (2016). Transforming the safety culture at New YorkCity Transit. People + Strategy, 39(1), 24-28.

Rotolo, C. T., Church, A. H., Adler, S., Smither, J. W., Colquitt, A. L., Shull, A. C., ... Foster, G. (2018). Putting an end to bad talent management: A call to action for the field of I-O -psychology. Industrial and Organizational Psychology: Perspectives on Science and Practice, 11(2), 176-219.

Sinar, E., and Grubb, A. (2018, April). Storytelling with impact: Mastering the practical science of influential communication. Workshop presented at the 33rd Annual Conference of the Society for Industrial and Organizational Psychology, Chicago, IL.

Winn, B, Bernstein, E., Harrell, E., Mathieu, J., Luciano, M., Rogers, K., \& Tavis, A. (2017). Publishing at the research-practice interface: Editors \& scholars share tips for real world impact. Paper presented at the 77th Meeting of the Academy of Management: Annual Conference, Atlanta, GA.

Winn, B., Luthans, F., Hayton, J., Tavis, A., Abel, A., \& Merino, M. (2015). Publishing beyond the Academy: Editors share tips on publishing for impact in the "real world". Paper presented at the 75th Meeting of the Academy of Management: Annual Conference, Philadelphia, PA.

Winn, B., Ulrich, D., Rucci, A., Bernstein, E., Merio, M., \& Tavis, A. (2016). Publishing for real world impact: Editors and researchers share tips on making research meaningful. Paper presented at the 76th Meeting of the Academy of Management: Annual Conference, Anaheim, CA.

\title{
Forever New Frontiers: Managing Messiness at the Edge
}

\author{
Paul R. Yost and Matthew S. Magill
}

Seattle Pacific University

A life's work is not a series of stepping-stones onto which we calmly place our feet, but more like an ocean crossing where there is no path, only a heading, a direction, which, of itself, is in conversation with the elements.

David Whyte, Crossing the Unknown Sea

Paul R. Yost, Seattle Pacific University; Matthew S. Magill, Seattle Pacific University.

Address correspondence to Paul R. Yost, Seattle Pacific University, Department of Industrial-Organizational Psychology, 3307 Third Avenue West, Suite 107, Seattle, WA 981191922. E-mail: yostp@spu.edu 
The future of talent management will always be discovered on the frontier, and the frontier is always messy. There will always be charlatans selling snake oil and the latest personality assessments. What can be done? When operating at the edge of the map, one cannot rely on having the right answers because the challenges and the answers will be novel. However, adventurers can rely on the capabilities and processes that allow them to adapt and figure it out as they go.

A critical question then emerges: What are the processes that can ensure that industrial and organizational (I-O) psychology is promoting positive talent management practices at the edge of what is known? Several factors already work in our favor. For example, our field is grounded in scientific empiricism and therefore has a systematic process to test new ideas and build on previous knowledge; the I-O psychology network includes both researchers and practitioners who share and argue ideas; and we actively work across a broad variety of organizations and at multiple levels within organizations (e.g., individual, team, system). Furthermore, several strategies have been proposed and adopted in our field to increase our ability to leverage the scientist-practitioner bridge (Avolio, 2017; Bartunek \& Rynes, 2014).

We propose three additional approaches that I-O psychologists should embrace to remain relevant on the frontier of talent management: (a) Adopt more action research methodologies; (b) learn how to sell I-O psychology; and (c) make humanitarian psychology central to our work. Although there are many potential solutions for dealing with anti-industrial-organizational psychology (AIO), these three strategies were selected because they address how I-O psychology can operate at the edge of our knowledge, they are actionable, and they can interact to enhance each another. In a dynamic environment, the three elements work together: action research enables adaptation, selling I-O psychology enables environmental acceptance, and humanitarian psychology provides direction. In the following sections we discuss the strategies in more depth, ways in which I-O psychology has leveraged the strategies in the past, and challenges to disseminate the strategies going forward.

\section{Adopt More Action Research}

As organizations are required to adapt more quickly to changing external realities, they have learned to be more innovative. Our work and research in I-O psychology could mirror this approach. The good news is that this might simply be going back to the future. Kurt Lewin (1946) introduced the concept of action research decades ago: find a problem, design a quick study, iterate, design another study, and iterate until a comprehensive answer emerges. As time progressed, we abandoned this territory (at least in our journals), favoring complex, well-designed research approaches that are also time 
consuming. Yet, the capacity for well-designed action research is possible. For example, emerging talent management processes can be studied to identify the issues that are at play (e.g., Church \& Rotolo, 2013), and examples of simple theory-driven research abound in our history (see Latham [2011] for instances where the author combined research and practice at Weyerhaeuser to advance both). I-O psychology has a long history of operating in the messy place where science and practice meet.

The opportunity to use action research methodologies could be a real asset where "fail fast" is an accepted part of an organization's culture. Big data provides the means to interactively test and refine talent management theories and processes. Making this knowledge a sustainable part of I-O psychology and testing talent management processes in ways that do not have strong, negative, unintended consequences can be challenging, but they are doable.

Two opportunities could significantly increase I-O psychology's capacity to operate in this space. First, organizations often guard their data. More effort in the future could be invested in practitioner-researcher partnerships, professional consortia (like the Mayflower Group), and expanding research samples beyond large corporations. Second, I-O psychology does not have a journal where applied action research can readily be published. This is arguably due to the value placed on high-quality, peer-reviewed research, which takes time and resources to produce. The quality of research is important. For example, one would be right to have misgivings about taking a new drug that has not undergone rigorous pharmaceutical testing. However, publishing in premier journals is costly and the lag time too great for most I-O practitioners. Consequently, results get presented at SIOP or the Academy of Management, and most are lost to time. Smaller, incremental studies rarely become part of the I-O knowledge repository. Comprehensive, rigorous studies are important but, in a highly dynamic environment, need to be complemented with a publication outlet for smaller, iterative studies. Hopefully, the IOP Practice Forum can begin to address this issue. This could provide a basis for answering both quick, iterative questions and larger high impact-high risk questions. As Karl Weick (1984) has noted, some social problems are so big that an iterative approach is the most effective.

\section{Selling I-O Psychology: If You Can't Beat Them, Join Them}

Rotolo et al. (2018), citing Miller and Hartwick (2002), note several characteristics of business fads that I-O psychologists should be able to do as well as, if not better than, AIO practitioners. After all, theory- and evidence-based approaches to science mirror what makes a good fad. They build on previous findings ("novel but not radical"), look for generalizable results ("onesize-fits-all" solutions), prioritize parsimonious theoretical explanations 
("simple"), and find ways to integrate talent management initiatives within other organizational processes ("easy to cut and paste").

Furthermore, if anyone should be able to leverage evidence-based practices to "sell" ideas, should it not be us? After all, psychology is the place to find research-based, applied strategies to persuade and make things stick (e.g., Cialdini, 2008; Heath \& Heath, 2007). Similarly, I-O psychology professionals know which practices are most likely to promote organizational change and intervention sustainability (Hedges \& Pulakos, 2002; Yost et al., 2011). For example, we know how to craft research-based practices to identify and involve key stakeholders, build top management support, and use feedback processes to improve program effectiveness.

Of course, it is one thing to know what to do and quite another to actually do it. I-O psychologists are well-trained to identify best practices logically and rationally. In their first jobs, many I-O psychologists tend to start conversations with phrases like "Research would suggest" but soon realize that this approach is not particularly compelling to most people. A host of other research-based influence tactics are available, such as inspirational appeals (Lee, Han, Cheong, Kim, \& Yun, 2017). In the future, we need to get much better at applying the influence tactics and change management processes that are readily available to us.

\section{For the Sake of What? Humanitarian I-O Psychology}

Action research gives I-O psychologists a way to meet some current organizational demands (particularly for haste) while maintaining some degree of empirical rigor and creating opportunities for "selling" ideas that will be adopted. However, as Rotolo et al. (2018) note, some talent management trends evolve so quickly that they are not answerable with empirical data. This brings us to a third strategy for operating at the edge: Use humanitarian I-O psychology to identify the questions that matter (Leftkowitz, 2010). Thus, even in the absence of knowing if a process will lead to higher organizational performance, we can sometimes determine the actions that will facilitate other important dimensions or enhance societal well-being.

Strong value positions are helpful because they provide a basis for alternative epistemologies and decision-making heuristics in the absence of empirical data. For example, values can (and should) be used to answer questions such as, is this talent management intervention morally right? Or, what are the ultimate goals and criteria that should be used to assess whether an appraisal process is "effective"? With a defined I-O psychologybased values system, Lefkowitz (2010) argues, "We'd still develop performance appraisal standards and evaluation systems but only if we were assured that the organization provides adequate means and opportunity 
for all employees affected to meet those standards and a safe mechanism for employee appeals" (p. 297). In the absence of an established moral values system, we risk reflexively adopting a business' values (Lefkowitz, 2008), which, depending on the business, can perpetuate AIO talent management.

Humanistic values and the treatment of employees have been discussed in the I-O psychology literature (Leavitt, 2007; Sikula, Olmosk, Kim, \& Cupps, 2001). However, some have argued that the moral and ethical values of our field are also often missing from the broader conversation (Katzell \& Austin, 1992; Salas, Kowzlowski, \& Chen, 2017). Consequently, we must surmise what humanistic I-O values (Lefkowitz, 2010) would look like beyond American Psychological Association ethical guidelines to further promote humanistic organizational theories and practices (Ghoshal, 2005). For example, in talent management, relevant questions include: What is a compensation structure that prioritizes (or at least does not undervalue) the dignity of workers? How can we design a process for contesting performance appraisals that creates the greatest social justice for all? Does our talent management system give all workers the opportunity to thrive?

\section{Conclusion}

In combination, these three practices-action research, selling I-O psychology, and humanistic I-O psychology-should significantly increase I-O psychology's ability to operate on the frontiers of talent management now and in the future. We know what to do ... time will tell if we do it.

\section{References}

Avolio, B. J. (2017). The practice and science connection: Let's not obsess over minding the gap. Industrial and Organizational Psychology, 10, 558-633.

Bartunek, J. M., \& Rynes, S. L. (2014). Academics and practitioners are alike and unlike: The paradoxes of academic-practitioner relationships. Journal of Management, 40, 1181-1201.

Church, A. H., \& Rotolo, C. T. (2013). How are top companies assessing their high-potentials and senior executives? A talent management benchmark study. Consulting Psychology Journal: Practice and Research, 65, 199-223.

Cialdini, R. B. (2008). Influence: Science and practice (5th ed.). Boston, MA: Allyn and Bacon.

Ghoshal, S. (2005). Bad management theories are destroying good management practices. Academy of Management Learning \& Education, 4, 75-91.

Heath, C., \& Heath, D. (2007). Made to stick: Why some ideas survive and others die. New York, NY: Random House.

Hedges, J., \& Pulokos, E. D. (2002). Implementing organizational interventions. San Francisco, CA: Jossey-Bass.

Katzell, R. A., \& Austin, J. T. (1992). From then to now: The development of industrial-organizational psychology in the United States. Journal of Applied Psychology, 77, 803-835.

Latham, G. P. (2011). Work motivation: History, theory, research and practice (2nd ed.). Thousand Oaks, CA: Sage Publications.

Leavitt, H. J. (2007). Big organizations are unhealthy environments for human beings. Academy of Management Learning \& Education, 6, 253-263. 
Lee, S., Han, S., Cheong, M., Kim, S. L., \& Yun, S. (2017). How do I get my way? A meta-analytic review of research on influence tactics. The Leadership Quarterly, 28, 210-228.

Lefkowitz, J. (2008). To prosper, organizational psychology should ... expand the values of organizational psychology to match the quality of its ethics. Journal of Organizational Behavior, 29, $439-453$.

Lefkowitz, J. (2010). Industrial-organizational psychology recurring identity crises: It's a values issue! Industrial and Organizational Psychology, 3, 293-299.

Lewin, K. (1946). Action research and minority problems. Journal of Social Issues, 2, 34-46.

Rotolo, C. T., Church, A. H., Adler, S., Smither, J. W., Colquitt, A. L., Shull, A. C., ... \& Foster, G. (2018). Putting an end to bad talent management: A call to action for the field of I-O psychology. Industrial and Organizational Psychology: Perspectives on Science and Practice, 11(2), 176-219.

Salas, E., Kozlowski, S. J., \& Chen, G. (2017). One hundred years of the Journal of Applied Psychology: Background, evolution, and scientific trends. Journal of Applied Psychology, 102, 237253.

Sikula, S. A., Olmosk, K., Kim, C. W., \& Cupps, S. (2001). A "new" theory of management. Ethics \& Behavior, 11, 3-21.

Weick, K. E. (1984). Small wins: Redefining the scale of social problems. American Psychologist, 39, 40-49.

Yost, P. R., McLellan, J., Ecker, D., Chang, G. C., Hereford, J., Roenicke, C., .. Winberg, Y. (2011). HR interventions that go viral. Journal of Business and Psychology, 26, 233-239.

\title{
Big Data Techniques and Talent Management: Recommendations for Organizations and a Research Agenda for I-O Psychologists
}

\author{
Michael C. Campion \\ Campion Services \\ University of Texas Rio Grande Valley \\ Michael A. Campion \\ Purdue University \\ Emily D. Campion \\ Old Dominion University
}

Big data and its applicability to talent management (TM) as defined by Rotolo et al. (2018) has already been recognized by many outside the field of I-O psychology. The market is beginning to include offerings from vendors for products that use some combination of big data techniques to process

Michael C. Campion, Campion Services and University of Texas Rio Grande Valley; Michael A. Campion, Purdue University; Emily D. Campion, Old Dominion University.

Correspondence concerning this article should be addressed to Michael C. Campion, Campion Services, 3336 Dubois St., West Lafayette, IN 47906. E-mail: michael@campionservices.com 